\title{
Treinamento auditivo em oficinas: opção terapêutica grupal $^{* * * *}$
}

\author{
Auditory training in workshops: group therapy option
}

\author{
Juliana Nunes Santos* \\ Isabel Cristina Plais do Couto** \\ Raquel Martins da Costa Amorim***
}

*Fonoaudióloga. Mestranda em Ciências da Saúde pela Universidade Federal de Minas Gerais. Endereço para correspondência: Rua Coronel Pedro Jorge, 170/201 - Belo Horizonte - MG CEP: 30.410-350

(juliana.santos@fead.br).

**Fonoaudióloga. Especialista em Audiologia pela FEAD - Minas Gerais.

***Fonoaudióloga. Mestre em Fonoaudiologia. Professora Titular do Curso de Graduação em

Fonoaudiologia e da Pós-Graduação

em Audiologia da FEAD - Minas

Gerais.

****Trabalho Realizado na Conclusão do Curso de Especialização em Audiologia da FEAD - Minas Gerais.

Artigo de Pesquisa

Artigo Submetido a Avaliação por Pares

Conflito de Interesse: não

Recebido em 20.07.2005.

Revisado em 10.09.2005; 02.06.2006; 12.09.2006.

Aceito para Publicação em 26.10.2006.

\begin{abstract}
Background: auditory training in groups. Aim: to verify in a group of individuals with mental retardation the efficacy of auditory training in a workshop environment. Method: a longitudinal prospective study with 13 mentally retarded individuals from the Associação de Pais e Amigos do Excepcional (APAE) of Congonhas divided in two groups: case $(n=5)$ and control $(n=8)$ and who were submitted to ten auditory training sessions after verifying the integrity of the peripheral auditory system through evoked otoacoustic emissions. Participants were evaluated using a specific protocol concerning the auditory abilities (sound localization, auditory identification, memory, sequencing, auditory discrimination and auditory comprehension) at the beginning and at the end of the project. Data (entering, processing and analyses) were analyzed by the Epi Info 6.04 software. Results: the groups did not differ regarding aspects of age (mean $=23.6$ years) and gender (40\% male). In the first evaluation both groups presented similar performances. In the final evaluation an improvement in the auditory abilities was observed for the individuals in the case group. When comparing the mean number of correct answers obtained by both groups in the first and final evaluations, a statistically significant result was obtained for sound localization $(p=0.02)$, auditory sequencing $(p=0.006)$ and auditory discrimination $(\mathrm{p}=0.03)$. Conclusion: group auditory training demonstrated to be effective in individuals with mental retardation, observing an improvement in the auditory abilities. More studies, with a larger number of participants, are necessary in order to confirm the findings of the present research. These results will help public health professionals to reanalyze the theory models used for therapy, so that they can use specific methods according to individual needs, such as auditory training workshops.
\end{abstract}

Key Words: Hearing; Speech Therapy; Mental Retardation; Public Health.

\section{Resumo}

Tema: treinamento auditivo em grupo. Objetivo: verificar a eficácia do treinamento auditivo em grupo de excepcionais no ambiente de oficinas. Método: estudo longitudinal prospectivo com 13 deficientes mentais da Associação de Pais e Amigos do Exepcional (APAE) de Congonhas, divididos em dois grupos: caso (n $=5)$ e controle $(n=8)$, e submetidos a 10 sessões de treinamento auditivo em grupo após verificação de integridade auditiva periférica por meio de emissões otoacústicas evocadas. Os participantes foram avaliados com protocolo específico quanto às habilidades auditivas (localização, identificação, memória, seqüência, discriminação e compreensão auditiva) no início e término do projeto. A entrada, processamento e análise dos dados foram realizados por meio do software Epi-Info 6.04. Resultados: os grupos não diferiram entre si quanto à idade (media $=23,6$ anos) e gênero, sendo $40 \%$ do masculino. Na avaliação inicial obteve-se desempenho semelhante dos grupos e na avaliação final, observou-se melhora nas habilidades auditivas dos indivíduos do grupo caso. Quando se comparou a média de acertos dos grupos caso e controle nas avaliações inicial e final obteve-se resultado estatisticamente significante nas provas de localização sonora $(p=0,02)$, seqüência auditiva ( $p=0,006)$ e discriminação auditiva ( $p=0,03$ ) Conclusão: o treinamento auditivo mostrou-se eficaz quando realizado em grupo de excepcionais no ambiente de oficinas, observando-se melhora nas habilidades auditivas dos indivíduos. Estudos com maior casuística são necessários para confirmar os achados deste estudo e para auxiliar os profissionais dos serviços públicos de saúde a repensarem o modelo teórico de atendimentos e a reorganizarem as demandas em seus locais de trabalho, traçando frentes de atuação distintas, vinculadas à realidade da população envolvida, tais como a oficina de estimulação auditiva em grupo.

Palavras-Chave: Audição; Fonoterapia; Educação; Retardo Mental; Saúde Pública.

Referenciar este material como: 


\section{Introduction}

Biologically, the majority of human beings are born with normal hearing and develop auditory abilities such as sound localization, discrimination, memory and recognition. However, the interaction between child and environment seems to determine the quality of development of these abilities (Ribas, 2001).

Recent researches have shown considerable evidences that the auditory training (AT) shall improve in several auditory processes, promoting a reorganization of the auditive neural substract. There are several changings in the morphology and auditive performance after the auditory training or constant sound stimulation. Younger brains have higher plasticity and can be rapidly modified (Musiek et al, 1999), and it has shown improvements in the individuals abilities who have taken the AT (Musiek e Berge, 1998; Gil et al 2000; Chaves et al, 2001; Schochat et al 2002).

In the communication sciences literature it is possible to find studies developed along with professors, parents, pregnants, elderly people and others suffering from language impairment, orofacial motricity, voice, reading and writing disorders. However, there are few studies about mentally retarded individuals focusing on hearing issues.

Furthemore, the effects of the auditory training at mentally retarded individuals are still unclear. The definition of this pathology verifies a notable reduction of the intellectual functioning under the average, associated to limitation of at least two aspects of the adaptative working: communication, personal care, daily activities, social abilities, assessing community resources, autonomy, health and safety, school skills, leisure time and working (DSM-IV,1995). However, it is known that the adaptative working of a person is influenced by several factors, including training, education, motivation, personality, social oportunities and skills, practical necessities and general health conditions. It is believed that adaptation problems get better over time, favoring independence/ interdependence, productivity, integration into the community (Assumpção Jr. e Sprovieri, 2000). Therefore, it is expected that AT is efficient when carried through groups at environment workshops (laboratory activities) that comes to improve the familiar interaction and the auditory perception performance of the mentally retarded since studies point to a malfunctioning of the auditory automatic answers of the mentally retarded brains (Ikeda et al, 2000).

From what has shown above, the objective of this current project is to verify the effectiveness of AT in mentally retarded groups at workshop environments, besides evaluating a possible correlation between the improvement of the auditory perception and the auditory behavior.

\section{Methods}

The entitled project "auditory training in workshops: group therapy option" was approved by the Research Ethical Committee Hospital Mater Dei in Belo Horizonte under protocol 074. The responsible party for the school authorized the execution of the project and the responsible one for the participants (students) was informed that the research was voluntary, was beneficial to society with possible repercussions. They signed the participation consentment.

This work was characterized by a prospective longitudinal study where 15 students registered at the Association of Parents and Friends of Exceptional (APAE) in Congonhas that had been going to the Living Center. The participants were divided by two groups, case group $(n=7)$ and control group $(\mathrm{n}=8)$. The choice of the individuals was random, being carried through for drawing in the APAE with the presence of teachers and supervisor of the institution.

It was defined as criteria of inclusion in the study to be registered in the APAE Congonhas, to participate at the Living Center which is already in the Institution, and to suffer from mentally retarded from low to moderate level.

As exclusion criteria, they had been established to present degenerative syndrome, to be hearing impaired from moderate to severe degree bilaterally, to be mental impaired that impossibilities the individual to participate of the evaluations and the activities proposals for the workshop and to get absence of evoked auditory answers in at last one ear.

First, the inspection of the external acoustic meatus was carried through to discard the presence of cerumen. Later, to test the cochlear integrity by means of the captation emissions evoked of the external ciliata cells, was done by the exam of the transient evoked otoacustic emissions and by product distortion at all participants (Andersson et al, 2000). The examinations have been carried through in the Speech-Language Pathology Center 
FEAD in Belo Horizonte with the equipment Madsen Capella of the GN Otometrics, model CE, serial number 459 . Those individuals who had gotten absence of answers in at least one of the ears had been excluded from the sample. In this way, excludes two individuals from the case group, remaining only thirteen individuals in the study, being five of the case group and eight of the control group.

The group case was constituted by five individuals being two (40\%) male gender and five $(60 \%)$ female gender. The average age of the participants was of 20, 6 years old, minimal age 14 years old and maximum age 26 years old.

The control group were formed by 8 participants being three of them (37,5\%) male gender and five $(62,5 \%)$ female gender. The average age was 26, 7 years old, minimum age 18 years old and maximum age 36 years old.

The participants had been assessed by a specific protocol related to the auditory abilities including tests such as localization, identification, memory, sequence, discrimination and auditory memory in the beginning and at the end of the project:

\section{Sound localization test}

Evaluated the ability to determine the location of the sound source. At a silent room was played a rattle at five different directions off the visual field and the patient was asked to identify the sound source. According to Pereira (1997), the stimulus might be presented to the right, left, behind, front and above the head and the correct answers for this test were: to get at least four directions correct out of five presented. The expected mistaken is at one of the directions (to the front, above, behind head) from three years old.

\section{Auditory identification test}

To evaluate the capacity and the meaning of certain auditory stimulus associated to the sound source. Three objects were selected to this new task: coin, comb and notebook. The assessed subject should identify the object which had fallen over the table through the racket that it produced. At first were presented the objects leaving them to fall on the table to the front of the subject. During the test application, a bulkhead device was used to avoid the visual support.
Auditory memory test

Aimed to evaluate the ability of recognition, retention and reproduction of auditory stimulus being that the memory do not depend on the exactly order that the sounds were presented. For this test were selected four group of words which the subject should listen to without visual clue and repeat them afterwards (Ribas, 2001). The evaluator should mark on sequence the words that the subject was able to reproduce. The presented words were:

1. Table, bed.

2. Pencil, eraser, pen.

3. Cat, dog, duck, chicken.

4. Hand, feet, mouth, eyes, nose.

Auditory sequence test

To evaluate the capacity of recognition, retention, and reproduction of the exactly sound stimulus that were presented. For this test were selected four groups of words where the individual should repeat the presented sequence according to the presented order. The evaluator marked each group of the words in order that were emitted. The words used were:

\section{Girafa, macaco.}

2. House, street, window.

3. Ball, dog, apple, car.

4. Cat, shoes, bed, mouth, book.

\section{Auditory discrimination test}

To evaluate the ability to perceive differences between the sound stimulus standards. The evaluator explained to the individual that he would listen to two words. After listening to that very carefully, the patient should say if they were equal or different. Before initiating the test were executed a training with three examples in order to verify if the patient discriminated the concepts of equality and difference. For this test were used a list of syllables patterns: cow- knife, ball-ball, pot - pot, plate - duck, room - room, lace - fig, frog - sac, pen - pen, bread - hand, feet - dust pan, chin - cheese, cola - sling, sweet -sweet, rose- wheel, comb - tooth.

Auditory comprehension test

To verify the ability to obtain a meaning of the auditory information. For this test were used five orders (Ribas, 2001): 
1. Get the ball.

2. Show the big ball.

3. Show your nose.

4. Show your shoes.

5. Put the spaghetti inside the yellow ball.

For this test were used spaghetti crumbles and three circles at three sizes and different colors (big yellow, small red and medium black). Before conducting the test, the evaluator presented the material naming the colors and sizes, certifying that each child were familiar with the concepts.

The AT workshop happened during the months of October to November 2004, twice a week, one hour and thirty minutes each session, totalizing 10 sessions. The projected were organized into thematic modules (musical instruments, body sounds, animal sounds, and environmental sounds) and including activities of identification, discrimination, attention, comprehension and auditory sequence. A lot of activities were done through AT, however, it is impossible to describe all of them in the current article. Therefore, it will be described one activity per thematic module.

first module: prioritized the work with musical instruments, such as: coconut, guizo, tambour, and rattle, triangle, base. The student manufactured their own instruments at the workshops (rattle and guizo), which were included at the auditory training.

Activity of auditory localization: it was executed an activity with the students sitting in circle, passing the ball around the circle while listening to music in the background. At the moment the song stopped the student who was holding the ball should play an instrument at the one of the sides of the room. The others, with eyes closed, should locate where the sound was coming from.

second module: it was emphasized the human body sounds (whistle, yawn, snore, sneezing, sniffling, blowing and applause, among others), which were produced by the students through games and theatricals presentations.

Auditory Identification Activity: the students received a sheet containing four figures representing the body sounds and they should execute a draw as soon as they listened. It is relevant to say that all the sounds were presented prior to the activity correlating to the drawings

third module: the central themes were sounds produced by the environment. In this module were used sounds recorded on a cassette tape and sound imitations in the auditory abilities workings.

Auditory sequence activity: auditory bingo. every subject received a pair of figures with different combinations. Each figure had sound recorded on a cassette tape correspondently. The sounds (opened tap, water falling in the cup, blender and hammer sounds) were played in groups of two by two. The students, who hold the card with the sequence correspondently, were the winner.

fourth module: prioritized the work with animal sounds, which were imitated by the students through theatrical presentation or recorded on cassette tape.

Auditory Memory Activity: every student received a sheet of paper containing five figures of animals. After listening to a three sequent sounds, the students should mark the drawn with an $\mathrm{x}$ independent of the presented order. Initially every animal and its respective sounds were presented to the students

The processing data were done by a structured input data bank specifically to this study on the Epi- Info 6.04 statistic program. The variables analyses were used the average as the central tendency measurement, variant as dispersion measurement and the ANOVA test. For analyzing of the categories variables were used the Exact Test of Fischer and adapted to the significant level of $5 \%$.

Identification of the sounds: body sounds
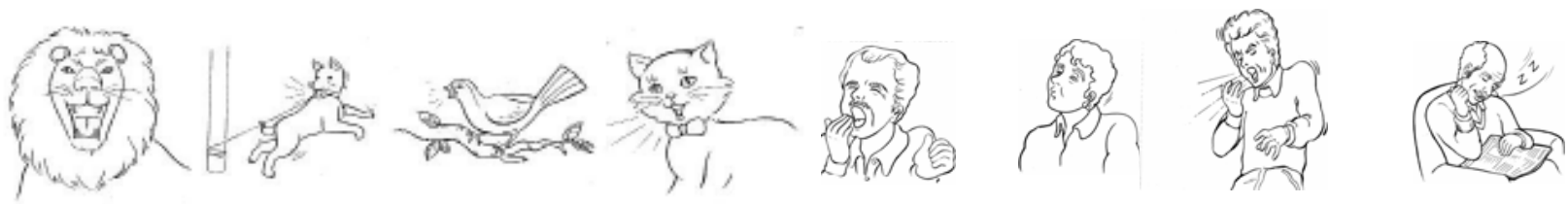


\section{Results}

The results of the individuals of every group case and control at these tests: location, identification, auditory memory are described in the tables 1,2 e 3 , respectively.

The results of the auditory sequence test are described according to the average of right, inversions and omissions at the tables 4 and 5, correspondently and respectively to the results in the initial assessments and at the final.

The results of the auditory discrimination and auditory comprehension are described in the tables 6 and 7, respectively. The results of the statistical analyzes in the table 8 .

TABLE 1. Results of the individuals of the auditory location test obtained by the individuals of the case group and control at the initial assessment and final.

\begin{tabular}{lcccccccc}
\hline \hline & \multicolumn{3}{c}{ Case Group } & \multicolumn{2}{c}{ Initial Assessment } & \multicolumn{2}{c}{ Final Assessment } \\
\multicolumn{2}{c}{} & \multicolumn{2}{c}{ Control Group } & & \multicolumn{2}{c}{ Case Group } & \multicolumn{2}{c}{ Control Group } \\
\hline Sound & $\begin{array}{c}\text { Frequency } \\
\text { of right }\end{array}$ & $\begin{array}{c}\text { Percentage of } \\
\text { right }\end{array}$ & $\begin{array}{c}\text { Frequency } \\
\text { of right }\end{array}$ & $\begin{array}{c}\text { Percentage of } \\
\text { right }\end{array}$ & $\begin{array}{c}\text { Frequency } \\
\text { of right }\end{array}$ & $\begin{array}{c}\text { Percentage of } \\
\text { right }\end{array}$ & $\begin{array}{c}\text { Frequency } \\
\text { of right }\end{array}$ & $\begin{array}{c}\text { Percentage of } \\
\text { right }\end{array}$ \\
\hline \hline To right & 05 & $100 \%$ & 08 & $100 \%$ & 05 & $100 \%$ & 07 & $88 \%$ \\
To left & 05 & $100 \%$ & 08 & $100 \%$ & 05 & $100 \%$ & 08 & $100 \%$ \\
Behind & 04 & $80 \%$ & 08 & $100 \%$ & 05 & $100 \%$ & 05 & $62,5 \%$ \\
To front & 04 & $80 \%$ & 05 & $62,5 \%$ & 04 & $80 \%$ & 05 & $62,5 \%$ \\
Above & 02 & $40 \%$ & 04 & $50 \%$ & 05 & $100 \%$ & 04 & $50 \%$ \\
\hline \hline
\end{tabular}

TABLE 2. Results of the individuals of the case group and control at the auditory identification test control at the initial assessment and final.

\begin{tabular}{|c|c|c|c|c|c|c|c|c|}
\hline \multirow[b]{3}{*}{ Objects } & \multicolumn{4}{|c|}{ Initial Assessment } & \multicolumn{4}{|c|}{ Final Assessment } \\
\hline & \multicolumn{2}{|c|}{ Case Group } & \multicolumn{2}{|c|}{ Control Group } & \multicolumn{2}{|c|}{ Case Group } & \multicolumn{2}{|c|}{ Control Group } \\
\hline & $\begin{array}{c}\text { Frequency } \\
\text { of right }\end{array}$ & $\begin{array}{l}\text { Percentage } \\
\text { of right }\end{array}$ & $\begin{array}{c}\text { Frequency } \\
\text { of right }\end{array}$ & $\begin{array}{c}\text { Percentage of } \\
\text { right }\end{array}$ & $\begin{array}{c}\text { Frequency of } \\
\text { right }\end{array}$ & $\begin{array}{c}\text { Percentage of } \\
\text { right }\end{array}$ & $\begin{array}{c}\text { Frequency } \\
\text { of right }\end{array}$ & $\begin{array}{c}\text { Percentage of } \\
\text { right }\end{array}$ \\
\hline Coin & 5 & $100 \%$ & 8 & $100 \%$ & 5 & $100 \%$ & 8 & $100 \%$ \\
\hline Comb & 5 & $100 \%$ & 7 & $87,5 \%$ & 5 & $100 \%$ & 7 & $87,5 \%$ \\
\hline Notebook & 5 & $100 \%$ & 8 & $100 \%$ & 5 & $100 \%$ & 8 & $100 \%$ \\
\hline total & 5 & $100 \%$ & 7,6 & $93,7 \%$ & 5 & $100 \%$ & 7,6 & $93,7 \%$ \\
\hline
\end{tabular}

TABLE 3. Results of the auditory memory obtained by the individuals of case group and control group in the initial assessment and final assessment.

\begin{tabular}{ccccccccc}
\hline \hline & \multicolumn{3}{c}{ Cnitial Assessment } & \multicolumn{2}{c}{ Final Assessment } \\
& \multicolumn{2}{c}{ Case Group } & \multicolumn{2}{c}{ Control Group } & \multicolumn{2}{c}{ Case Group } & \multicolumn{2}{c}{ Control Group } \\
\hline Words & $\begin{array}{c}\text { Frequency } \\
\text { of right }\end{array}$ & $\begin{array}{c}\text { Percentage of } \\
\text { right }\end{array}$ & $\begin{array}{c}\text { Frequency } \\
\text { of right }\end{array}$ & $\begin{array}{c}\text { Percentage of } \\
\text { right }\end{array}$ & $\begin{array}{c}\text { Frequency } \\
\text { of right }\end{array}$ & $\begin{array}{c}\text { Percentage of } \\
\text { right }\end{array}$ & $\begin{array}{c}\text { Frequency } \\
\text { of right }\end{array}$ & $\begin{array}{c}\text { Percentage of } \\
\text { right }\end{array}$ \\
\hline \hline 2 words & 02 & $100 \%$ & 1,8 & $93,7 \%$ & 02 & $100 \%$ & 2,0 & $100 \%$ \\
3 words & 2,8 & $92,3 \%$ & 2,6 & $87,4 \%$ & 3,0 & $100 \%$ & 2,6 & $87,4 \%$ \\
4 words & 3,4 & $85 \%$ & 2,6 & $65,6 \%$ & 3,8 & $90 \%$ & 2,7 & $68,7 \%$ \\
5 words & 3,6 & $72 \%$ & 2,2 & $45 \%$ & 4,4 & $88 \%$ & 2,5 & $50 \%$ \\
Total & 11,8 & $84,3 \%$ & 9,5 & $67,8 \%$ & 13,2 & $94,3 \%$ & 9,9 & $70,5 \%$ \\
\hline \hline
\end{tabular}


TABLE 4. Results of the auditory sequence test obtained by individuals of the case group and control in the initial assessment.

\begin{tabular}{|c|c|c|c|c|c|c|c|c|c|c|}
\hline & \multicolumn{5}{|c|}{ Case Group } & \multicolumn{5}{|c|}{ Control Group } \\
\hline & $\begin{array}{c}02 \\
\text { words }\end{array}$ & $\begin{array}{c}03 \\
\text { words }\end{array}$ & $\begin{array}{c}04 \\
\text { words }\end{array}$ & $\begin{array}{c}05 \\
\text { words }\end{array}$ & Total & $\begin{array}{c}02 \\
\text { words }\end{array}$ & $\begin{array}{c}03 \\
\text { words }\end{array}$ & $\begin{array}{c}04 \\
\text { words }\end{array}$ & $\begin{array}{c}05 \\
\text { words }\end{array}$ & Total \\
\hline Frequency right & 02 & 03 & 01 & 0,4 & 6,4 & 1,0 & 1,6 & 0,9 & 0,7 & 4,2 \\
\hline Percentage right & $100 \%$ & $100 \%$ & $25 \%$ & $8 \%$ & $45,7 \%$ & $50 \%$ & $54,2 \%$ & $21,8 \%$ & $15 \%$ & $30,3 \%$ \\
\hline $\begin{array}{l}\text { Frequency } \\
\text { inversions }\end{array}$ & 00 & $00 \%$ & 1,8 & 0,0 & 1,8 & 0,75 & 0,8 & 0,12 & 00 & 1,6 \\
\hline $\begin{array}{l}\text { Percentage } \\
\text { inversions }\end{array}$ & $00 \%$ & $00 \%$ & $45 \%$ & $00 \%$ & $12,8 \%$ & $37,5 \%$ & $25 \%$ & $3,1 \%$ & $00 \%$ & $11,6 \%$ \\
\hline $\begin{array}{l}\text { Frequency } \\
\text { omissions }\end{array}$ & 00 & 00 & 1,2 & 4,6 & 5,8 & 0,25 & 0,6 & 3,0 & 4,3 & 8,1 \\
\hline $\begin{array}{l}\text { Percentage } \\
\text { omissions }\end{array}$ & $00 \%$ & $00 \%$ & $30 \%$ & $92 \%$ & $41,5 \%$ & $12,5 \%$ & $20,8 \%$ & $75 \%$ & $85 \%$ & $58 \%$ \\
\hline
\end{tabular}

TABLE 5- Results of the auditory sequence obtained by individuals of case group and control in the final assessment.

\begin{tabular}{|c|c|c|c|c|c|c|c|c|c|c|}
\hline & \multicolumn{5}{|c|}{ Case Group } & \multicolumn{5}{|c|}{ Control Group } \\
\hline & $\begin{array}{l}02 \\
\text { words }\end{array}$ & $\begin{array}{c}03 \\
\text { words }\end{array}$ & $\begin{array}{c}04 \\
\text { words }\end{array}$ & $\begin{array}{c}05 \\
\text { words }\end{array}$ & Total & $\begin{array}{c}02 \\
\text { words }\end{array}$ & $\begin{array}{c}03 \\
\text { words }\end{array}$ & $\begin{array}{c}04 \\
\text { words }\end{array}$ & $\begin{array}{c}05 \\
\text { words }\end{array}$ & Total \\
\hline Frequency right & 02 & 03 & 01 & 0,8 & 6,8 & 1,1 & 1,4 & 0,3 & 0,0 & 2,8 \\
\hline Percentage righ & $100 \%$ & $100 \%$ & $25 \%$ & $16 \%$ & $48,6 \%$ & $56,2 \%$ & $45,9 \%$ & $6,3 \%$ & $00 \%$ & $19,6 \%$ \\
\hline $\begin{array}{l}\text { Frequency } \\
\text { inversions }\end{array}$ & 00 & $00 \%$ & 1,4 & 1,4 & 2,8 & 0,5 & 0,9 & 0,1 & 00 & 1,5 \\
\hline $\begin{array}{l}\text { Percentage } \\
\text { inversions }\end{array}$ & $00 \%$ & $00 \%$ & $35 \%$ & $28 \%$ & $20 \%$ & $25 \%$ & $29,1 \%$ & $3,1 \%$ & $00 \%$ & $10,7 \%$ \\
\hline $\begin{array}{l}\text { Frequency } \\
\text { omissions }\end{array}$ & 00 & 00 & 1,6 & 2,8 & 4,4 & 0,38 & 0,75 & 3,6 & 5,0 & 9,7 \\
\hline $\begin{array}{l}\text { Percentage } \\
\text { omissions }\end{array}$ & $00 \%$ & $00 \%$ & $40 \%$ & $56 \%$ & $31,4 \%$ & $18,8 \%$ & $25 \%$ & $90,6 \%$ & $100 \%$ & $69,6 \%$ \\
\hline
\end{tabular}

TABLE 6 -Results of auditory discrimination obtained by individuals of case group and control group in the initial assessment and final.

\begin{tabular}{lcccccccc}
\hline & \multicolumn{2}{c}{ Initial Assessment } & & \multicolumn{2}{c}{ Final Assessment } \\
& \multicolumn{2}{c}{ Case Group } & \multicolumn{2}{c}{ Control Group } & \multicolumn{2}{c}{ Case Group } & \multicolumn{2}{c}{ Control Group } \\
& Frequency & Percentage & Frequency & Percentage & Frequency & Percentage & Frequency & Percentage \\
\hline \hline $\begin{array}{l}\text { Average } \\
\text { right }\end{array}$ & 10,0 & $66,6 \%$ & 9,8 & $65,6 \%$ & 13,6 & $90,6 \%$ & 11,0 & $73,3 \%$ \\
\hline \hline
\end{tabular}


TABLE 7. Results of auditory comprehension obtained by individuals in the case group and in the control group at the initial assessment and final assessment

\begin{tabular}{|c|c|c|c|c|c|c|c|c|}
\hline & \multicolumn{4}{|c|}{ Initial Assessment } & \multicolumn{4}{|c|}{ Final Assessment } \\
\hline & \multicolumn{2}{|c|}{ Case Group } & \multicolumn{2}{|c|}{ Control Group } & \multicolumn{2}{|c|}{ Case Group } & \multicolumn{2}{|c|}{ Control Group } \\
\hline & Frequency & Percentage & Frequency & Percentage & Frequency & Percentage & Frequency & Percentage \\
\hline $\begin{array}{l}\text { Average } \\
\text { right }\end{array}$ & 4,8 & $96 \%$ & 4,25 & $85 \%$ & 4,2 & $84 \%$ & 4,3 & $87,5 \%$ \\
\hline
\end{tabular}

TABLE 8. Comparing the average of right answers in the auditory abilities tests .in the case group and control group.

\begin{tabular}{|c|c|c|c|c|c|c|}
\hline \multirow{2}{*}{ Auditory Abilities } & & \multicolumn{2}{|c|}{ Case Group (n=5) } & \multicolumn{2}{|c|}{ Control Group $(\mathrm{n}=8)$} & \multirow[b]{2}{*}{$\mathrm{P}$} \\
\hline & & Average right & Variant & Average right & Variant & \\
\hline \multirow{2}{*}{ Auditory Localization } & Initial Assessment & 4,0 & 0,50 & 4,12 & 0,41 & 0,34 \\
\hline & Final Assessment & 4,8 & 0,2 & 3,6 & 0,84 & $* 0,02$ \\
\hline \multirow{2}{*}{ Auditory Memory } & Initial Assessment & 11,8 & 1,7 & 9,5 & 4,0 & $* 0,04$ \\
\hline & Final Assessment & 13,2 & 0,7 & 9,9 & 4,41 & $* 0,004$ \\
\hline \multirow{2}{*}{ Auditory Sequence } & Initial Assessment & 6,8 & 1,3 & 4,25 & 17,1 & 0,23 \\
\hline & Final Assessment & 6,8 & 1,2 & 2,75 & 7,37 & $* 0,006$ \\
\hline \multirow{2}{*}{ Auditory Discrimination } & Initial Assessment & 10 & 10 & 9,9 & 9,5 & 0,93 \\
\hline & Final Assessment & 13,6 & 0,8 & 11,0 & 5,33 & $* 0,03$ \\
\hline Auditory & Initial Assessment & 4,8 & 0,2 & 4,25 & 0,5 & 0,14 \\
\hline Comprehension & Final Assessment & 4,2 & 1,2 & 4,4 & 0,83 & 0,75 \\
\hline
\end{tabular}

* Teste ANOVA

\section{Discussion}

At the initial evaluation at the location of the sound source was possible to observe that $80 \%$ of the participants of the case group and $75 \%$ of the participants of the control group executed the location of the sound source at least at four out of five directions, what is considered a regular result (Pereira, 1997). It was observed, at the final assessment, that the performance of the case group was superior of the control group (Table 1 ), being that $100 \%$ of the participants of the case group had presented regular results against $63 \%$ regularity of the control group participants. The case group obtained $100 \%$ of improvement at four out of five tasks of sound localization while the control group only at the left localization obtained this rate, presenting a medium rate $73 \%$ of right answers totally against $96 \%$ of right answers of the case group. A work done with 80 normal hearing children, age between 4 and 6 years, showed that 93\% presented normal answers at the sound source localization (Ribas, 2001). While compared to the performance of the case group before and after the auditory training, it was observed a statistical significant improvement $(p=0,02)$, which proves the efficiency of the AT relating to the ability to the sound localization.

At the identification sound test, was able to observe that the two groups presented good performance at this ability that in the first assessment which has not differentiate relating to the second assessment (TAB. 2). These findings demonstrated that this ability is presented among the mentally impaired individuals with normal hearing, not being influenced by a possible malfunctioning of the cerebral automatic answers (Ikeda et al, 2000).

It was revealed that a similar performance among the participants of the case group and control in the sequences of two, three words at the memory test at the initial evaluation. In the sequence of four and five words was a better performance of the case group than the control group, with a significant statistical ( $p=0,04)$, being that the group case and control presented, respectively, an average 11, 8 e 9, 5 right trials at a total of 14 words. 
At the final evaluation, it was revealed that an increasing of the gap between the groups, with better answers were at the group case. Considering to the total test score of the groups, the case group and control presented respectively 13, 2 and 9, 9 right answers that shows the effectiveness of the auditory training relating to the auditory memory. These findings are in concordance with the prior study which has studied 80 children normal hearing, that showed that the auditory memory is influenced by the social environment, being favored according to the quality of the provided stimulation (Ribas, 2001).

At the auditory sequence test, at the initial evaluation, was observed that the performance of the case group was a little better than the control group (TAB. 4), presenting rates of right answers and higher inversions and a smaller omission rate. However, there was not a statistical significance between the groups relating to the average of the right answers $(p=0,23)$. At the auditory sequence test in the final assessment (TAB.5) the difference that existed between the groups in the initial assessment was more relevant and increasing from ressalted $33 \%$ to $59 \%$ in the right rate, from $1,6 \%$ to $63,8 \%$ in the inversion rate from $38,5 \%$ to 19 , and $6 \%$ in the omissions rate. The inversions rate was an important milestone in the case group, since in the initial evaluation the groups presented the same and in the final evaluation the difference between them were equal $63 \%$, in other words, they were omitting and inverting the words orders. The improvement in the ability of auditory sequence was confirmed statistically $(p=0,006)$, showing the efficiency of AT in this ability. The brazilian study done in 2002 with 20 individuals from eight to twenty-four years old individuals showed effectiveness of AT, being that $85 \%$ of the patients improved with the treatment (Schochat et al, 2002).

At the auditory discrimination test, in the initial evaluation (TAB. 6), the groups presented a similar performance, not being observed a difference statistical significant $(p=0,93)$. It is relevant that this test, the individuals from both groups had difficulties in the execution, since that, some of them did not know the meaning of equality and difference that were necessary for the test in order to be done. Therefore, the participants that did not get to finish the task after a initial training with three patterns of words and the explanation of the concepts, were asked to repeat the words according to the auditory perception. At the final evaluation, it was observed a better improvement of the individuals in the case group, what was proved statistically $(\mathrm{p}=0,03)$.
At the auditory comprehension (TAB.7), was observed that the groups obtained similar results before and after the training, showing that the way that the training was done did not interfere directly into this ability, however has been observed an improvement at other auditory abilities which contributed to the existence of a better auditory performance in the individuals undergone treatment.

It can be said that AT was effective, been verified an improvement of the auditory abilities, according to well known international authors, that believe the improvement in those abilities probably appeared as an answer to the environment influence (Musiek e Berge, 1998). The affectivity of the AT was verified as well in national studies (Gil et al 2000; Chaves et al, 2001; Schochat et al 2002).

This effectiveness can be justified by the presence of the auditory neural system plasticity associated to the stimulation of auditory abilities, considered to be fundamental for the development and the use of the regular language (Aita e Mesquita, 2003).

According to previously studies (Hugenneryer e Oliveira, 2000; Panhoca e Penteado, 2003) can be said that the group workshop shared similar experiences, as well the possibility of facing difficulties and the abilities in front of each other, contributing to the group growth.

Besides that, the participants enjoyed a therapeutically environment emphasized in the mutual participation and in the game, what has decreased the group anxiety and promoted motivational learning (Ide, 1997, Dias 2000). The participants worked hard to do the activities, they helped handing out the papers and they felt very proud when were asked to demonstrate their abilities.

It can be said that according to the division of the therapeutical groups existed in the public service (Silva et al, 2003), that the patients were grouped according to their needs, being that the treatment focused on the pathology impairment, in other words, were stimulated to development of auditory abilities, speech, language, cognition, among others, and the therapeutical objectives were focused on the functionality, socialization and emphasizing the auditory behavior.

This currently study evidenced the effectiveness of the AT, as well the capacity of learning of the mentally impaired (Assumpção Jr. e Sprovieri, 2000), especially concerning about the auditory abilities.

Moreover, the assessment of these abilities provided the following process if the mentally retarded participants throughout the training (Musiek et al, 1999), and showed an improvement at the auditory function of these individuals. 


\section{Conclusion}

The AT has shown been efficient when executed with exceptional groups in the workshop environment, observing an improvement significant statistical in the abilities of localization, discrimination and auditory sequence.

The work in group has shown the efficiency not only in the measurable aspects of the auditory behavior but also as a stimulator of the social development, communication, linguistic and cognition, creating and brilliant learning context.
Studies with a better casuistic and a follow-up training are fundamental to confirm the data that were presented here.

The present study should help professionals from health public service to reformulate the theoretical model of assessment and to reorganize the demand in their workplaces, setting new distinctive assessments as the auditory stimulation in groups.

\section{References}

AITA, A. D. C.; MESQUITA, C. D. Correlação entre as desordens do processamento auditivo central e queixas de dificuldades escolares. J. Bras. Fonoaudiol., v. 4, n. 15, p. 101-107, 2003.

ANDERSSON, E.; ARLINGER, S.; JACOBSSON, S. Evaluation of OAE-recording as a compelmentary test method for adults with moderate to profund mental retardation. Scand Audiol., v. 29, n. 2, p. 120-126, 2000.

ASSUNPÇÃO JUNIOR, F. B.; SPROVIERI, M. H. Introdução ao estudo da deficiência mental. São Paulo: Memnon, 2000. cap. 3, p. 21-28.

CHAVES, R. D.; AMATUCCI, M. A. F.; ASSENCIOFERREIRA, V. J. Treinamento auditivo: estudo de caso R. Cefac, v. 3, p. 191-194, 2001

DIAS, R. S. Criar jogos: uma proposta de atuação fonoaudiológica. R. Cefac, v. 2, n. 21, p. 71-77, 2000.

DSM - IV. Manual diagnóstico e estatístico de transtornos mentais. Trad. Dayse Batista. 4. ed. Porto Alegre: Artes Médicas, 1995. p. 39.

GIL, D.; ALMEIDA, C. C.; PHEE, A. M.; ARTONI, A. A.; PELLOGIA, C. C.; ANTUNES, F.; PEREIRA, L. D. Efeito do treinamento auditivo para percepção musical nos testes de padrão de freqüência e duração. Acta Awho, v. 19, n. 2, p. 64-67, 2000.

HUGENNEYER, A. G.; OLIVEIRA, S. M. R. P. Terapia fonoaudiológica em grupo: um caminho possível. $R$. Soc. Bras. Fonoaudiol., v. 4, n. 6, p. 19-23, jun. 2000.

IDE, S. M. Linguagem do deficiente mental: desafio à educação. Pró-Fono R. Atual. Cient., Carapicuíba (SP), v. 9, n. 2, p. 3-10, set. 1997.
IKEDA, K.; OKUZUMI, H.; HAYASHI, A.; HASHIMOTO, S.; KANNO, A. Automatic auditory processing and even-related brain potentials in persons with mental retardation. Percept. Motor Skills, n. 91, p. 1145-1150, 2000.

MUSIEK, F. E.; BARAN, J.; CHOCHAT, E. Selected management approaches to central auditory processing disorders. Scan Audiol., v. 28, n. 51, p. 63-76, 1999.

MUSIEK, F. E.; BERGE, B. A neuroscience view of auditory training stimulation and central auditory processing disorders. In: MASTERS, M. G.; STECKER, M. A.; KATZ, J. Central auditory: processing disorders (mostly management). Boston: Allyn and Bacon, 1998. cap. 2, p. 15-24.

PANHOCA, I.; PENTEADO, R. Z. Grupo terapêutico fonoaudiológico: a construção conjunta da linguagem e da subjetividade. Pró-Fono R. Atual. Cient., Barueri (SP), v. 15, n. 3, p. 259-266, set.-dez. 2003

PEREIRA, L. D. Processamento auditivo central: abordagem passo a passo. In: PEREIRA, L. D.; SCHOCHAT, E. Processamento auditivo central: manual de avaliação. São Paulo: Lovise, 1997. cap. 5, p. 49-59.

RIBAS, A. A influência do meio social sobre o desenvolvimento da percepção auditiva em crianças. $J$. Bras. Fonoaudiol., v. 2, n. 8, p. 224-228, 2001.

SCHOCHAT, E.; CARVALHO, L. Z.; MEGALE, R. Treinamento auditivo: avaliação da manutenção das habilidades. Pró-Fono R. Atual. Cient., Barueri (SP), v. 14, n. 1, p. 93-99, jan.-abr. 2002.

SILVA, F.; DIAS, M. V. C.; MATSUSHITA, T.; DOURADO, M. T. M. Organização de grupos terapêuticos no serviço público municipal de São José dos Campos. R. Fonoaudiol. Bras., p. 22-27, jun. 2003. 